\title{
Climate Smart Agriculture: Achievements and Prospects in Africa
}

\author{
Adornis D. Nciizah, Isaiah I. C. Wakindiki \\ Agricultural Research Council-Institute for Soil Climate and Water, Pretoria, South Africa \\ Email: wakindikii@arc.agric.za
}

Received 29 July 2015; accepted 22 August 2015; published 25 August 2015

\begin{abstract}
Smallholder agriculture is facing a myriad of challenges in the wake of a changing climate. To counter this, several measures have been suggested in attempts to reduce the vulnerability of smallholder farmers who are the worst affected by changes in climate. However, despite these interventions not much improvement in agricultural production has been realized by the smallholder farmers. This suggests the need for more alternative options for these resource poor farmers. One such intervention is climate smart agriculture (CSA), which is probably one of the most viable and sustainable options. It offers both mitigation and adaptation measures to climate changes. However, problems of its viability and sustainability have been raised by several authors who argue that there are barriers, limits and costs, which may hinder its adoption by farmers. This review discusses the achievements attained so far in improving the productivity of smallholder agricultural soils under changing climatic conditions. The review also looks at the prospect of CSA with regards to South African smallholder agriculture.
\end{abstract}

\section{Keywords}

Adaptation, Mitigation, Recovery, Soil Health, Soil Management

\section{Introduction}

Food security is a fundamental constitutional right in South Africa, especially among the historically disadvantaged population. However, soil erosion, runoff, and high evapotranspiration are among the top challenges limiting soil and water productivity in South Africa and thus threatening food security (Bennie \& Hensley, 2004) [1]. Some of the obvious consequences of these challenges posed by land degradation include loss of fertile top soil and contamination of surface water bodies (Bennie \& Hensley, 2004) [1]. In addition to anthropogenic land degradation, climate change further compounds food production with the effects more pronounced in the smallholder sector of the developing world (IPCC, 2007) [2]. Predicted changes in climate include fluctuating rainfall patterns, increases in drought frequency and floods, which negatively affect crop yield, livestock production, fisheries and forestry. This is especially true under rainfed conditions. In this regard, interventions aimed at holistically dealing with all the myriad challenges facing African agriculture have now become more imperative than ever before.

Consequently, experts, policy makers and other actors concerned with rural livelihoods and food security 
have recommended climate smart agriculture (CSA) as a sure means of reducing the deleterious effects of climate change in the smallholder farming sector (FAO, 2010; World Bank, 2014; NEPAD 2015; FANRPAN, 2012) [3]-[6]. Moreover, the Food and Agriculture Organization (FAO, 2010) [3] highlighted that agriculture in developing countries must undergo a substantial transformation in order to meet the related challenges of food security and climate change. The adoption of climate smart agriculture (CSA) as an adaptation strategy is envisaged to help smallholder farmers adapt to climate change by intensifying or diversifying their livelihood strategy. Climate smart agriculture is agriculture that sustainably increases productivity, resilience (adaptation), reduces/removes greenhouse gases (GHGs) (mitigation), and enhances achievement of national food security and development goals. It is composed of three main pillars:

1) sustainably increasing agricultural productivity and incomes;

2) adapting and building resilience to climate change;

3) reducing and/or removing greenhouse gases emissions, where possible

In short, CSA generally focuses on ensuring not only food security but nutrition security as well to rural and smallholder farmers across Africa and other developing communities. In addition, CSA has a holistic approach since it also aims to protect or restore the resource base. International institutions such as the World Bank, African Development Bank (ADB) have been at the forefront in trying to complement efforts by FAO to promote CSA in Africa. Other organizations include NEPAD and FANRPAN continue to work on promoting resilient and sustainable livelihoods for smallholder farmers in Africa. For instance, the Food, Agriculture and Natural Resources Policy Analysis Network (FANRPAN) in partnership with the International Development Research Centre (IDRC), the African Capacity Building Foundation (ACBF), Norad and the Rockefeller Foundation is currently involved in several initiatives aimed at CSA in several African countries, i.e. Angola, Botswana, Democratic Republic of the Congo, Kenya, Lesotho, Madagascar, Malawi, Mauritius, Mozambique, Namibia, South Africa, Swaziland, Tanzania, Uganda, Zambia and Zimbabwe. These initiatives include:

- The Evidence-Based Policies for Climate Smart Agriculture (EPCSA);

- Strengthening Evidence-Based Climate Change Adaptation Policies (SECCAP);

- Strengthening Institutional Capacity on Climate Smart Agriculture (SICCSA);

- Limpopo Basin Development Challenge (LBDC).

Briefly, some of the most important objectives of the FANRPAN CSA programme include: conducting comprehensive analysis of CSA policies, programmes and institutional arrangements in the earlier mentioned focal countries, generating CSA research-based evidence and ing the uptake and up-scaling of CSA practices as best practice in Africa (FANRPAN, 2012) [6].

Similarly, NEPAD launched an alliance of diverse partners known as the Africa Climate-Smart Agriculture Alliance in 2014 tasked with reaching six million farming families through CSA processes (NEPAD, 2014) [5]. Broadly, the alliance seeks to contribute to helping 25 million farmers become more resilient and food secure by 2025. The World Bank also recognizes that scaling up CSA to adapt farming systems to climate change and mitigate the impact of climate change has the capacity to assist millions of farmers in low-income countries (Reichwage, 2014) [7]. The Bank is likewise actively involved in funding CSA initiatives in Africa and the rest of world. The World Bank's CSA work plan focuses on three main areas, i.e.

- better use of existing knowledge;

- filling knowledge gaps;

- supporting global dialogue and action through investing in climate smart agriculture.

All these initiatives by International Institutions in conjunction with National Organizations have the capacity to synergistically ensure resilient smallholder farming systems, thus ensuring food security in the wake of climate change. This paper is not an attempt to discuss the frame work of CSA but seeks to highlight the successes achieved so far and the future prospects in the African context. Therefore the paper will highlight achievements achieved thus far since the implementation of CSA in certain smallholder communities of South Africa with respect to previous production systems.

\section{Management of Agricultural Soils under Smallholder Farming Systems in South Africa}

The Department of Environmental Affairs [DEA] (2013) [8] describes the South African Agriculture sector as a two-tiered, agricultural system, which on one hand consists of commercial farmers and on the other hand small- 
holder and subsistence farmers. Smallholder farmers consist of 1.3 million farming households on an estimated 14 million hectares of agricultural land. They are mainly concentrated in the former homeland areas of the country and are consequently marginalized into regions of poor productive land, with little or no infrastructural support and water resources. Resultantly, the smallholder farmers have low levels of production efficiency, and engage in agricultural production to supplement their household food requirements, with surplus sold at local markets if available. Moreover, they lack sufficient farm management skills and hence high production inefficiency. Lastly, productivity is further compounded by poor support services directed at the smallholder farmers in terms of financial services, technical support, access to transport and other support infrastructure (DAFF, 2011) [9]. As such, these poor farmers cannot afford expensive technologies and resort to poor agricultural practices, which have resulted in extreme losses of topsoil and the creation of large gullies. Instead, use of locally available and/or cheap technologies combined with making the best of natural, social, and human resources may be the best option (Pretty, 2009) [10]. As such, CSA may be the most plausible solution for these farmers if food sufficiency is to be attained.

\section{Principles of Climate Smart Agriculture}

As earlier mentioned CSA has three focal areas i.e. sustainably increasing agricultural productivity and incomes, adapting and building resilience to climate change, reducing and/or removing greenhouse gases emissions, where possible. Adapting and building resilience to climate change is especially important since it ensures food sufficiency despite unsuitable conditions. Resilience is defined as the ability of a social or ecological system to absorb disturbances while retaining the same basic structure and ways of functioning, the capacity for self-organization, and the capacity to adapt to stress and change (IPCC, 2007) [2]. The Rockefeller Foundation (2009) [11] went on to specifically define climate resilience as the capacity of an individual, community, or institution to dynamically and effectively respond to shifting climate impact circumstances while continuing to function at an acceptable level. This is achieved through several soil management practices that sequester carbon in the soil, reduce greenhouse gas (GHG) emissions and aid intensify production (FAO, 2013) [12]. Above all the practices must enhance the natural resource base. Therefore, the most important premise of CSA is the building of healthy soils (Magdoff, 2007; Stabinsky \& Ching, 2012) [13] [14] through increasing the soil organic matter (SOM) status of the soil (Blanco-Canqui \& Lal, 2004) [15]. Soil management practices for CSA include; direct seeding under no/reduced-tillage (Zheng et al., 2014) [16]; improved protective soil cover through cover crops, crop residues or mulch (Muzangwa et al., 2013) [17]; and crop diversification through rotations (Lin, 2011; Davis et al., 2012) [18] [19]. Moreover, integrated soil fertility management, which includes both inorganic and organic sources and considers combining inputs of organic matter i.e. mulch, compost, crop residues and green manure with fertilizers to address or prevent macro- and micro-nutrient deficiencies should be carefully considered (FAO, 2013) [12].

\section{Achievements Attained under Climate Smart Agriculture in South Africa}

In addition to initiatives from NEPAD, FANRPAN, World Bank, CSA is promoted by national research councils such as the Agricultural Research Council (ARC) and government department like the Department of Agriculture Forestry and Fisheries (DAFF), the Department of Rural Development and Land Reform (DRDLR), non-governmental organisations (NGOs) e.g. African Conservation Trust (ACT) are actively promoting CA in the smallholder farming sector in South Africa. The activities of these organizations have seen the transformation of rural communities in which they are operating. For instance, DRDLR in conjunction with the ARC-Institute for Soil, Climate and Water (ARC-ISCW) is implementing a project aimed at promoting conservation agri- culture technologies (CATs) in several rural communities in the Eastern Cape and Kwa-Zulu Natal provinces. The focus of the project is on the demonstration and assessment of CA technologies with the aim of ensuring sustainable land use and management of the natural resources while enhancing food production, entrepreneurial development and job creation. To date, the project has seen job creation through the temporary employment of people in the wards hosting the projects. The project has seen increases in maize especially in the Eastern Cape Province. The project has also imparted water harvesting knowledge to the participants i.e. both for domestic use from roofs gutters and in-field rain water harvesting (IRWH).

More examples include projects funded by ACT in the smallholder farming sector in South Africa. The organization implemented widespread training and implementation of ecological micro-farms which are now pro- 
viding fresh vegetables and fruit to 27,000 people each year in over 40 schools and 250 individual gardens (ACT, 2013) [20]. This alone shows the ability of CSA to feed rural populations. Other programmes by ACT include replanting indigenous forests and building capacity in natural resource harvesting and assisting communities to harvest rainwater for homestead gardens, and reducing soil erosion in two major catchment areas of the Ukhahlamba Drakensberg Park World Heritage Site. These programmes are estimated to directly benefit 40,000 people.

Similarly the Department of Agriculture forestry and Fisheries (DAFF) is promoting projects that include principles of CSA across South Africa. It is generally agreed that it is in developing countries that some of the most significant progress toward sustainable agroecosystems has been made in the past decade (Actionaid, 2007) [21]. Pretty et al. (2006) [22] showed the extent to which 286 recent interventions in 57 poor countries covering 37 million ha (3\% of the cultivated area in developing countries) have increased productivity on 12.6 million farms while improving the supply of critical environmental services. The average crop yield increase was $79 \%$. All crops showed water use efficiency gains, with the highest improvement in rainfed crops whilst the potential carbon sequestered amounted to an average of $0.35 \mathrm{t} \mathrm{C} \mathrm{ha}^{-1} \cdot \mathrm{y}^{-1}$. The interventions used included; integrated pest management, integrated nutrient management, conservation tillage, cover crops, agroforestry, aquaculture, water, livestock reintegration and mixed crop-livestock systems.

Another significant project implemented under the CSA was the Limpopo Basin Development Challenge (LBDC) initiated by the Challenge Program on Water and Food (CPWF) led by FANRPAN, GWP SA and WaterNet in Limpopo province (FANRPAN, 2012) [6]. The aim of the project was to improve governance and management of rainwater and small water infrastructure in the Limpopo basin to raise productivity, reduce poverty, and improve livelihoods resilience. The broad aim of the project was to promote the inclusion of science based evidence basin decision making toward improved smallholder productivity and reduced risk in rainfed agricultural production systems achieved through; research coordination, on-going engagement with stakeholders and innovation research. Preliminary findings of the study showed the importance of community buy-in and support as necessary pre-conditions for any wide spread adoption. This led to the conclusion that a thorough understanding and diagnosis of the socio-technology nexus is a necessary pre-condition for impact FANRPAN (2012) [6]. The second important achievement of the project was the appreciation of the role of different types of livestock in mixed production such as those found in the Limpopo Basin, which helps better tailor research and interventions to meet household and community needs.

Another success story is that of ActionAid which initiated by the Gamopedi Food Garden Project in Gamopedi Village in South Africa in 2009. The farming group received 2 hectares of land from the local Chief to start growing vegetables. The farmers were trained on soil and water conservation through the use of green manure and composts, crop rotation, intercropping, and ridge tillage by ActionAid South Africa. This has seen a marked improvement in crop productivity with the farmers now able to produce sufficient food for their families, supplying schools, day nurseries and sick people and selling the surplus crops to the wider village community (ActionAid, 2007) [21]. More success stories from around Africa are shown in Table 1. These success stories show that ecological has a big role to play in improving agricultural production in the smallholder farming sector and also show the need for different organization to continue working with smallholder farmers in promoting sustainable agriculture.

\section{Possible Challenges and Prospects of Climate Smart Agriculture}

There is a lot of skepticism about the ability of CSA to mitigate the effects of climate by fostering soil resilience and let alone feed communities. This is in spite of the potential benefits of the system especially to the smallholder farmers who bear the brunt of the effects of climate. Most of the farmers are resource poor and their usually own land in marginal areas. According to Ortmann and Mache the (2003) [25], there are more than three million smallholder famers owning less than 1.3 hectares in marginal with low yields. CSA would be the most appropriate system for such farmers since it uses locally available resources and does not rely on the use of external inputs (Magdoff, 2007)[13]. Nonetheless, in a review on adapting crops and cropping systems to future climates, Matthews et al. (2013) [26] highlighted that most recommended adaptations will involve several trade-offs. For example, (Pretty, 2009) [10] points out that, farmers cannot simply cut their existing use of such inputs as fertilizer or pesticides and hope to maintain outputs and neither can they introduce a new productive element into their farming systems, and hope it succeeds. Instead the transition costs arise for several reasons, 
Table 1. Success of climate smart agriculture in some parts of Africa (Actionaid, 2007; Pretty et al, 2006; Lim, 2009; FAO, 2015) [21]-[24].

\begin{tabular}{|c|c|}
\hline Country & Findings \\
\hline Burkina Fasso and Niger & $\begin{array}{l}\text { Soil and water conservation in the drylands have transformed formerly degraded lands. The average } \\
\text { family has shifted from being in cereal deficit of } 644 \mathrm{~kg} \text { per year (equivalent to } 6.5 \text { months of food } \\
\text { shortage) to producing an annual surplus of } 153 \mathrm{~kg} \text {. }\end{array}$ \\
\hline Ethiopia & Some 12,500 households have adopted conservation agriculture, resulting in a $60 \%$ increase in crop yields. \\
\hline Ethiopia & Yields of crops from composted plots were 3 - 5 times higher than those treated only with chemicals. \\
\hline Senegal & $\begin{array}{l}\text { Projects promoted stall-fed livestock, composting systems, green manures, water harvesting systems and } \\
\text { rock phosphate. Yields of millet and peanuts increased dramatically by } 75 \% \text { - 195\% and } 75 \%-165 \% \\
\text { respectively. }\end{array}$ \\
\hline Kenya & $\begin{array}{l}\text { In Kenya, } 500 \text { farmers on some } 1000 \text { hectares have seen maize yields improve from about } 2 \text { to } 4 \text { t/ha } \\
\text { following the application of soil conservation, soil fertility and organic agriculture methods. }\end{array}$ \\
\hline Kenya & $\begin{array}{l}\text { A range of biological pest management methods together with legumes, cover crops and green manures for } \\
\text { soil fertility improvement resulted in a doubling of beans and groundnut yields from } 300 \text { to } 600 \mathrm{~kg} / \mathrm{ha} \text {. }\end{array}$ \\
\hline Kenya & $\begin{array}{l}\text { Smallholder farmers were trained in natural soil fertility management; integrated environmentally friendly } \\
\text { weed, pest and disease protection; on-farm soil and water conservation techniques; and farm level seed } \\
\text { conservation, with a resulting } 50 \% \text { increase in productivity and } 40 \% \text { increase in income. }\end{array}$ \\
\hline Kenya & $\begin{array}{l}\text { More than } 1000 \text { farmers in low soil fertility areas increased maize yields to } 3414 \mathrm{~kg} / \mathrm{ha} \text { ( } 71 \% \text { increase in } \\
\text { productivity) and bean yields to } 258 \mathrm{~kg} / \mathrm{ha}(158 \% \text { increase in productivity) as compared to traditional } \\
\text { agriculture, by incorporating soil fertility management, crop diversification and improved crop } \\
\text { management. }\end{array}$ \\
\hline Malawi & $\begin{array}{l}\text { Integration of pond fish culture into low-input farm systems with some } 2000 \text { farmers increased vegetable } \\
\text { yields from } 2700 \text { to } 4000 \mathrm{~kg} / \mathrm{ha} \text {, with the fish ponds producing the equivalent of } 1500 \mathrm{~kg} / \mathrm{ha} \text { of fish, a new } \\
\text { source of food for households. }\end{array}$ \\
\hline South Africa & $\begin{array}{l}\text { Soil and water conservation through the use of green manure and composts and various techniques such as } \\
\text { crop rotation, intercropping, and ridge tillage has seen an increase in crop productivity. }\end{array}$ \\
\hline Tanzania/Kenya & $\begin{array}{l}\text { Through the FAO Mitigation of Climate Change in Agriculture (MICCA) Programme, } 2500 \text { farmers } \\
\text { received training on CSA resulting in; } 300 \text { energy-efficient cooking stoves to reduce deforestation } \\
\text { - } \quad 44 \text { tree nurseries } \\
\text { - } \quad 134,381 \text { seedlings in stock and more than 33,500 tree seedlings planted } \\
\text { - } \quad 235 \text { terraces established to conserve soil and water } \\
\text { - } \quad 2 \text { biogas digesters to produce renewable energy from cow manure }\end{array}$ \\
\hline Mount Kilimanjaro & $\begin{array}{l}\text { FAO's Globally Important Agricultural Heritage Systems Initiative (GIAHS), activities were piloted in } 660 \\
\text { households to enhance farmers' cash income while preserving the ecological and social integrity of the } \\
\text { Kihamba system. The following results are expected; } \\
\text { - Rehabilitation of the irrigation system to reduce water loss and expansion of the capacity of storage } \\
\text { ponds to cope with longer dry seasons due to climate change. } \\
\text { - Training in sustainable land management. } \\
\text { - The interventions in coffee management alone are expected to increase farm cash income by } 25 \text { percent } \\
\text { in three years. }\end{array}$ \\
\hline
\end{tabular}

which include the following;

1) Farmers must first invest in learning about a greater diversity of practices and measures.

2) Farmers need to acquire information and management skills.

3) During the transition and learning period, farmers must experiment more, and incur the costs of making mistakes as well as of acquiring new knowledge and information.

4) New technologies often require more labor.

Moreover, specific policies and interventions for implementing CSA depend on the social and biophysical contexts in which farmers operate, which calls for different solutions for large farms with good market access and high input use, small farms with good market access and high input use, and small farms with low market access and low input use (Dobermann \& Nelson, 2013) [27]. However, Dobermann and Nelson (2013) [27] offered a possible solution to this by suggesting the implementation of the following processes;

1) Diagnosis: which entails understanding the context in which an effort or intervention will be implemented 
and its links to global agro-ecological knowledge.

2) Contextualized principles: by identifying the right economic, social and ecological principles of relevance to farmers' needs.

3) Getting it right locally: through empowering local communities to improve the performance of the farming system based on agro-ecological principles and local preferences.

4) Scaling and support: by expanding the scope of the effort or intervention (in terms of numbers of people involved and the size of the territory) and create the necessary value chains, services, support systems and self-sustained business models.

5) Evidence: through monitoring and documenting the performance, and learning to enrich the local and global knowledge base to influence policies that will support further implementation.

\section{Concluding Remarks}

Africa faces a lot of challenges in meeting food requirements in the face of an ever changing climate. With water becoming scarce and flooding becoming more frequent, it has led to a reduction in quality for the soil as a resource base, so interventions are required to guarantee the restoration of the resource base and become more imperative. Therefore, the need for adaptation and mitigation measures is now stronger than ever before. It therefore becomes imperative to look for alternatives. In this regard, CSA offers a viable and sustainable solution since it is based on the creation of healthy soil through integrated soil-crop system management. The overall goal is the attainment of optimal crop yield of a high quality with low negative environmental effects. By implementing CSA, the resilience of smallholder farmer soils may be preserved since soil quality management is central in ecological management. If properly implemented with provision of the necessary support, CSA will also improve productivity and food security in the smallholder farming sector as shown by the examples cited in this review. It is, however, important not to use a one size to fit all approach in implementing CSA principles in the smallholder farming sector. It is thus essential to firstly identify the precise economic, social and ecological principles of relevance to farmers' needs probably through participatory research. Since farmers are likely to adopt a measure that ensures multiple benefits such as high efficiency, diversity, self-sufficiency, self-regulation, and resiliency adoption, CSA is likely to be high within the smallholder sector. Smallholder farmers in South Africa may also draw inspiration from success stories in other parts of Africa. However, specific policies and interventions for implementing CSA are needed to guide the implementation of CSA and perhaps provide incentives to smallholder farmers as an encouragement.

\section{Acknowledgements}

This work was supported by the Agricultural Research Council-Institute for Soil Climate \& Water.

\section{References}

[1] Bennie, A.T.P. and Hensley, M. (2013) Advances in Soil Physics and Soil Water Management Research in South Africa, 1979-2003. South African Journal of Plant and Soil, 21, 268-277. http://dx.doi.org/10.1080/02571862.2004.10635063

[2] IPCC (2007) Climate Change: Impacts, Adaptation and Vulnerability. Contribution of Working Group II to the Fourth Assessment Report of the Intergovernmental Panel on Climate Change. In: Parry, M.L., Canziani, O.F., Palutikof, J.P., van der Linden, P.J., Hanson, C.E., Eds, Cambridge University Press, Cambridge.

[3] FAO (2010) Climate-Smart Agriculture Policies, Practices and Financing for Food Security, Adaptation and Mitigation. http://www.fao.org/docrep/013/i1881e/i1881e00.pdf

[4] World Bank (2014) Foster Climate-Smart Agriculture. https://www.worldbank.org/en/topic/agriculture/brief/foster-climate-smart-agriculture

[5] NEPAD (2014) Millions of African Farmers to benefit from new Climate Smart Agriculture Alliance. http://www.nepad.org/print/3361

[6] FANRPAN (2012) FANRPAN at the 2nd Limpopo LBDC Reflection Workshop. http://www.fanrpan.org/documents/d01310/

[7] Reichwage, M. (2014) World Bank: Smart Investments in Triple Win Agriculture. http://ciatblogs.cgiar.org/support/world-bank-smart-investments-in-triple-win-agriculture/\#sthash.JTSQFtLi.dpuf 
[8] DEA (Department of Environmental Affairs) (2013) Long-Term Adaptation Scenarios Flagship Research Programme (LTAS) for South Africa. Climate Change Implications for the Agriculture and Forestry Sectors in South Africa. Pretoria, South Africa.

http://www.sanbi.org/sites/default/files/documents/documents/ltassummary-policy-makers2013high-res.pdf

[9] DAFF (2011) South African Agricultural Production Strategy. http://www.daff.gov.za/doaDev/doc/IGDP/AGRIC_PRODUCTION_STRATEGY_FRAMWK.pdf

[10] Pretty, J.N. (2009) Can Ecological Agriculture Feed Nine Billion People? Monthly Review: An Independent Socialist Magazine, 61, 46-58.

http://monthlyreview.org/2009/11/01/can-ecological-agriculture-feed-nine-billion-people/

[11] Rockefeller Foundation (2009) Building Climate Change Resilience. Rockefeller Foundation White Paper. http://www.rockefellerfoundation.org/uploads/files/c9725eb2-b76e-42eb-82db-c5672a43a097-climate.pdf

[12] FAO (2013) Climate-Smart Agriculture Sourcebook. Food and Agriculture Organization of the United Nations, Rome. http://www.fao.org/docrep/018/i3325e/i3325e04.pdf

[13] Magdoff, F. (2007) Ecological Agriculture: Principles, Practices, and Constraints. Renewable Agricultural Food Systems, 22, 109-117. http://dx.doi.org/10.1017/S1742170507001846

[14] Stabinsky, D. and Ching, L. (2012) Ecological Agriculture, Climate Resilience and a Roadmap to Get There. TWN Environment \& Development Series No. 14, Third World Network, Penang.

[15] Blanco-Canqui, H. and Lal, R. (2004) Mechanisms of Carbon Sequestration in Soil Aggregates. Critical Reviews in Plant Science, 23, 481-504. http://dx.doi.org/10.1080/07352680490886842

[16] Zheng, C., Jiang, Y., Chen, C., Sun, Y., Feng, J., Deng, A., Song, Z., et al. (2014) The Impacts of Conservation Agriculture on Crop Yield in China Depend on Specific Practices, Crops and Cropping Regions. The Crop Journal, 2, 289-296. http://dx.doi.org/10.1016/j.cj.2014.06.006

[17] Muzangwa, L., Chiduza, C. and Muchaonyerwa, P. (2013) Feasibility of Winter Cover Crop Production under Rainfed Conditions in the Eastern Cape Province of South Africa. African Crop Science Journal, 21, 73-184.

[18] Lin, B.B. (2011) Resilience in Agriculture through Crop Diversification: Adaptive Management for Environmental Change. BioScience, 61, 183-193. http://dx.doi.org/10.1525/bio.2011.61.3.4

[19] Davis, A.S., Hill, J.D., Chase, C.A., Johanns, A.M. and Liebman, M. (2012) Increasing Cropping System Diversity Balances Productivity, Profitability and Environmental Health. PLoS ONE, 7, e47149. http://dx.doi.org/10.1371/journal.pone.0047149

[20] ACT (2013) Reducing Food Insecurity through Conservation Agriculture. http://www.givengain.com/cause/3213/projects/10862

[21] ActionAid (2007) Climate Resilient Sustainable Agriculture (CRSA): Experiences from Action Aid and Its Partners. http://ag-transition.org/?initiative=climate-resilient-agriculture-experiences-from-action-aid-and-its-partners

[22] Pretty, J., Noble, A.D., Bossio, D., Dixon, J., Hine, R.E., Penning de Vries, F.W. and Morison, J.I. (2006) ResourceConserving Agriculture Increases Yields in Developing Countries. Environmental Science and Technology, 40, 11141119.

[23] Lim, L.C. (2009) Is Ecological Agriculture Productive? TWN Briefing Paper No. 52, Third World Network, Penang.

[24] FAO (2015) FAO Success Stories on Climate-Smart Agriculture. http://www.fao.org/3/a-i3817e.pdf

[25] Ortmann, G. and Machethe, C. (2003) Problems and Opportunities in South African Agriculture. In: Nieuwoudt, L. and Groenewald, J., Eds., The Challenge of Change: Agriculture, Land and the South African Economy, Univ. Natal Press, Pietermaritzburg, 47-62.

[26] Matthews, R.B., Rivington, M., Muhammed, S., Newton, A.C. and Hallet, P.D. (2013) Adapting Crops and Cropping Systems to Future Climates to Ensure Food Security: The Role of Crop Modelling. Global Food Security, 2, 24-28. http://dx.doi.org/10.1016/j.gfs.2012.11.009

[27] Dobermann, A. and Nelson, R. (2013) Sustainable Development and Planetary Boundaries. Background Paper for the High-Level Panel of Eminent Persons on the Post-2015 Development Agenda. Prepared by the Co-Chairs of Sustainable Development Solutions Network Thematic Group on Sustainable Agriculture and Food Production. http://www.post2015hlp.org/wp-content/uploads/2013/06/Rockstroem-Sachs-Oehman-Schmidt-Traub Sustainable-De velopment-and-Planetary-Boundaries.pdf 